\title{
Environmental Management Methods for Trunk Road Adjacent Urban Areas
}

\author{
Oleksiy Priymachenko \\ Kyiv National University of Construction and Architecture \\ Povitroflotskyi Avenue 31, Kyiv, Ukraine, 03680 \\ priymachenko a@ukr.net, orcid.org/0000-0001-5125-8472
}

Received 06.04.2019, accepted after revision 08.06.2019

https://doi.org/10.31493/tit1909.1802

\begin{abstract}
The efficient operation of all types of transport is an essential condition for the stable operation of Ukrainian economy. Since the transport industry of Ukraine is closely connected to almost all branches of production and social sphere, its trends in development follow the general dynamics of the country's economic development. At the same time, transport industry's development priorities should take into account the distinguishing features of road transport as a fast, convenient, mobile, socially significant mode of transport whose activities are subject to certain safety and environmental risks and guided by international regulatory and legal codes and standards. Today there are more than 1 million trucks and approx. 7 million cars in Ukraine, and this number is growing. This, in turn, leads to an increase in fuel and energy resources consumed by motor vehicles.

Raising requirements on the ecological condition of the urban environment causes a problem in the effective planning and functioning of protective and planning elements of trunk road adjacent areas. Trunk road adjacent areas are those located along the main street and road network within the boundaries from the trunk road to the construction line. These are the boundaries of the location of houses and structures related to the red lines, according to the construction line definition. They account for about $15 \ldots 30 \%$ of the city's area. The study of methodological foundations of sustainable development of urbanized areas should be based on a comprehensive, problem-oriented approach of various related scientific studies. Therefore, the task of studying the environmental impact of the main street network is relevant for the city. Thus, the city's main street and road network
\end{abstract}

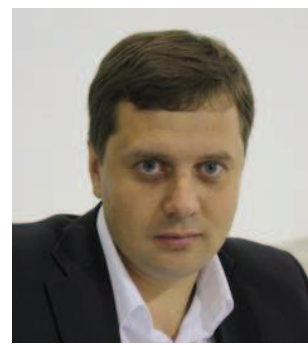

Oleksiy Priymachenko Assistant Professor of the City Urban Planning and Development $\mathrm{PhD}$, Ass. Prof.

can be called the main source of complex ecological impacts, particularly on the intra-city environment and the environment, i.e. the urban ecosystem as a whole. All-natural components of the urban environment, namely, geological, atmospheric, hydrological environment, are subject to harmful anthropogenic impact of the street and road network. The most critical is the atmospheric air condition, whose deterioration is a planetary scale problem.

Keywords: ecological condition of urban environment, trunk road adjacent area, environmental impacts.

\section{PROBLEM STATEMENT}

This study purpose is to explore and develop the methodological foundations of regulating environmental and urban planning processes of functioning and developing the main street and road network under the influence of environmental impacts from traffic flows and external factors.

Information support development, scientific research and scientifically based complex solutions and methods of choosing planning and management options for trunk road adjacent areas are required. The main task of the 
study is a creation of environmental management models in determination of the effectiveness of environmental and urban planning regulation of the operating and development processes of trunk road adjacent areas. Moreover, modelling of the main street and road network transversal profiles with the possible setting of the size of the areas between trunk roads to reduce the intensity of environmental impacts on the residential building area is required, too.

\section{RECENT RESEARCH AND PUBLICA- TIONS ANALYSIS}

The relevance of this research topic is indicated by the analysis of scientific works and urban development codes and standards in effect. This research topic is the subject of research by renowned scientists such as:

- V.I.Nudelman, M.M.Domin, Ye.Ye.Kliushnichenko, H.I.Lavryk, M.M.Habrel, Yu.M. Bilokon, I.O.Fomin, M.M.Kushnirenko, A.P. Ositnianko, O.I.Synhaivska, A.M. Pleshkanovska, H.Y.Filvarov in urban and territorial planning issues;

- B.V.Solukha, M.M.Osietrin, Ye.O.Rejtsin, D.S.Samoilova, V.I.Huk, T.O.Shilova, M.S.Fishelson, M.S.Murza, A.Ya.Tulaieva, H.L. Karaban, Z.I.Aleksandrovska, Yu.L. Shevchenko, V.S.Weinberg, I.B. Solukha, O.S.Furmanenko, I.I. Ustinova etc. in theoretical and scientific-methodical system studies in the aspect of transport and ecological problems.

\section{STATEMENT OF BASIC MATERIAL}

The main challenges of the ecological condition of trunk road adjacent areas are the negative impact of the transportation flow, which in turn generates environmental impacts in the form of noise, air pollution and contamination of areas.

As a result of the studies in the propagation of environmental noise impact under current urban conditions, cross-sectional profile models of trunk road adjacent areas have been developed, with the definition of their calculated noise impact, and the methodological basis for ecological and urban planning regulating the processes of functioning and development of the main street and road network at the stages of regional and local planning of the area have been proposed.

As a result of research on the distribution of noise ecological impacts, the technique of defining noise impacts in calculation points has been proposed, assuming the effect of existing planning solutions of trunk road adjacent areas influence and planning solutions on civil construction improvements of the area, arrangement solutions for the relief surface, use of civil structures and planning methods for the protection of trunk road adjacent areas.

The reliability of the proposed models is demonstrated by calculating the modelling results of various planning solutions and the results of field studies. The basis of the fullscale study is made by the most typical crosssection profiles of Kyiv trunk road adjacent areas:

- The trunk road network sites in the densely built-up conditions;

- The trunk road network sites passing through varied terrain relative to the level of the main street and road network;

- The trunk road network sites passing through undeveloped, i.e. building-free, area;

- The trunk road adjacent area sites in the context of the built-up area influence on the value of the environmental impact indicators in the middle of a built-up area.

Noise impact indicators and their action potential were determined at the sites under study.

The model for determining the distribution of environmental noise impacts from the main street and road network on the territory is based on the introduction of the standard indicator $\mathbf{L}_{\text {stand., }}$ which is an indicator of the noise level and obtained under conditions of noise modelling on a plane. In order to determine the calculated noise level at the design site, the calculated indicator Lcalc., assuming appropriate corrections and the impact of the trunk road adjacent area planning solutions. The expression for calculating Lcalc. contains the constant index $\mathbf{K}_{\mathbf{c o n s t}}$ (index of transition to urban environment) obtained as a studies 
result of modelling of noise propagation on the surface and the coefficient of accounting for civil construction improvements of the area within arrangements for the terrain of trunk road adjacent areas $K_{\text {calc. }}$ which is based on scientifically developed surface models with street and road networks of various altitudes. The proposed noise indicator calculation method will provide a clear picture of the environmental impact on its planning and spatial arrangements on the trunk road adjacent area and the management of main street and road networks.

The formula for calculating the noise indicator at the calculation point:

$$
L_{\text {calc. }}=L_{\text {stand. }} * K_{\text {const }} * K_{\text {calc. }}+L_{\text {a surf. }}+L_{\text {a slope }} \text { (1) }
$$

where $\mathrm{L}_{\text {calc. }}$ is the calculated value of noise indicator at a given point;

$L_{\text {stand. }}$ is the standard value of noise indicator at a given point on a plane terrain;

$K_{\text {const. is the constant coefficient of merging }}$ to urban environment, 0.95 ;

$K_{\text {calc. }}$ is the coefficient for civil construction improvements of the area committed to terrain arrangements of trunk road adjacent areas;

$L_{a}$ surf. is the correction (dBA) to take into account the type of carriageway or road surface;

$L_{a}$ slope - is the correction (dBA) to take into account the longitudinal slope of the street or road.

The aforementioned calculation model testifies to the universality of the developed approach with scientific substantiation of methodology of definition of indicators of environmental noise impacts and forecasting of required design solutions on the choice of civil design solutions of protective arrangements and the extent of civil construction improvements of the area in order to define the area's functional purpose so as to plan and deploy comfortable environment. According to the research, graphs for determining the standard noise value $\mathbf{L}_{\text {stand. }}$ (Fig. 1) and transverse profile models of the main street and road networks with the $\mathbf{K}_{\text {calc. }}$ factor based on the terrain specifics of the trunk road adjacent area (Fig. 2) have been developed.
The introduction of the term EPI "Ecological Planning Indicator of Stable Area Development" was proposed as a result of the study of the criteria for assessing possible environmental impacts and the extent of the area's required planning and civil construction improvements, taking into account impact factors, their quantitative and specific indicators. So,

$$
E P I=\left(E_{1} n_{1} ; E_{2} n_{2} ; \ldots . ; E_{n} n_{m}\right),
$$

where $E_{n}$ is the type of environmental impact on the area;

$n_{m}$ is the potential for civil construction protective measures over space and time cov-



Fig. 1. Graphs for determining the standard noise value $\mathrm{L}_{\text {stand }}$

ering an area of a relevant factor.

The proposed model outlines in detail the extent of the environmental impact on the area, predicts the consequences and methods of civil construction improvements of the area, forms the criteria of functional purpose and the basis for choosing protective elements and methods against the predicted environmental impacts on the urban environment.

Thus, according to the stage of development of planning and build-up diagrams of the area at regional and local levels, it is possible to make suitable planning solutions for 


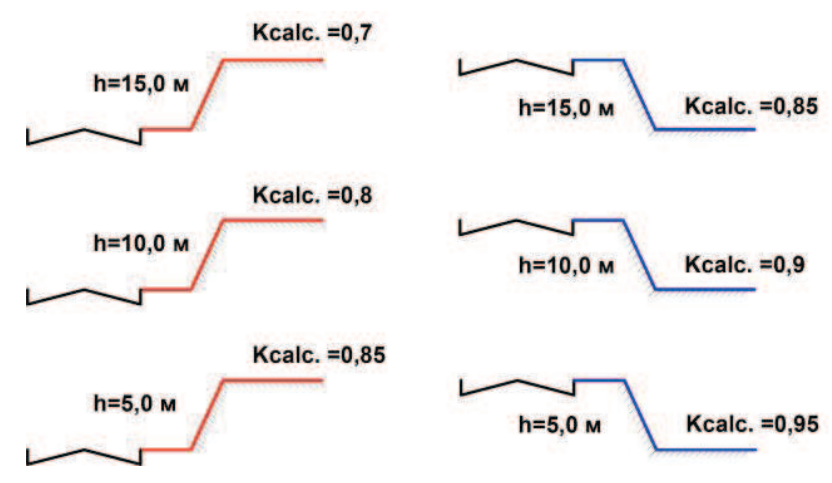

Fig. 2. Transverse profile models of main street and road networks with the environmental impact reduction factor $\mathrm{K}_{\text {calc }}$

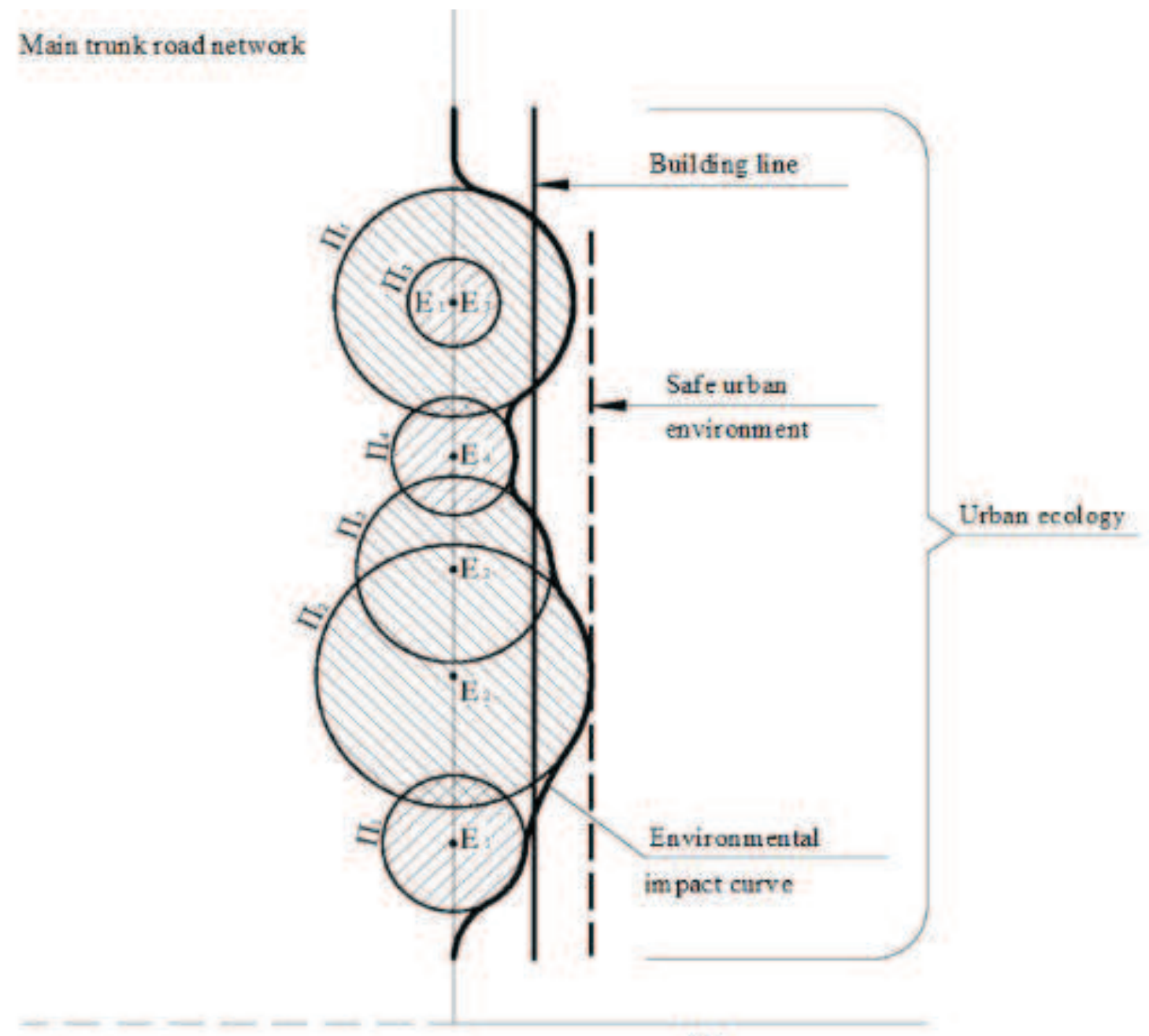

Urban area

Fig. 3. The model of efficiency of environmental and urban planning regulation of the processes of functioning and development of the trunk road adjacent areas 
he development of these areas and to provide expert assessment of existing planning solutions from the point of view of ecology both under conditions of free build-up of the area sign) and under conditions of existing buildup (area renovation).

On the ground of the research completed, a model was developed (Fig. 3) for assessing environmental impacts on the trunk road adjacent area with possible forecasting of the planning and technical solutions required for substantiation and an integrated approach to urban area planning at the stages of development of the area planning and development diagrams:
- at regional level: settlement planning, its functional area zoning, with noise protection zones to be allocated;

- at the city master plan stage: street and road network routing of the trunk level; functional area zoning with the building line to be allocated;

- separation of residential areas; use of the surface area as a protective element;

- formation of a green space system as a protective element; and

- extension and rational use of trunk road adjacent areas.

Based on this methodology for assessing environmental impacts and forecasting effects

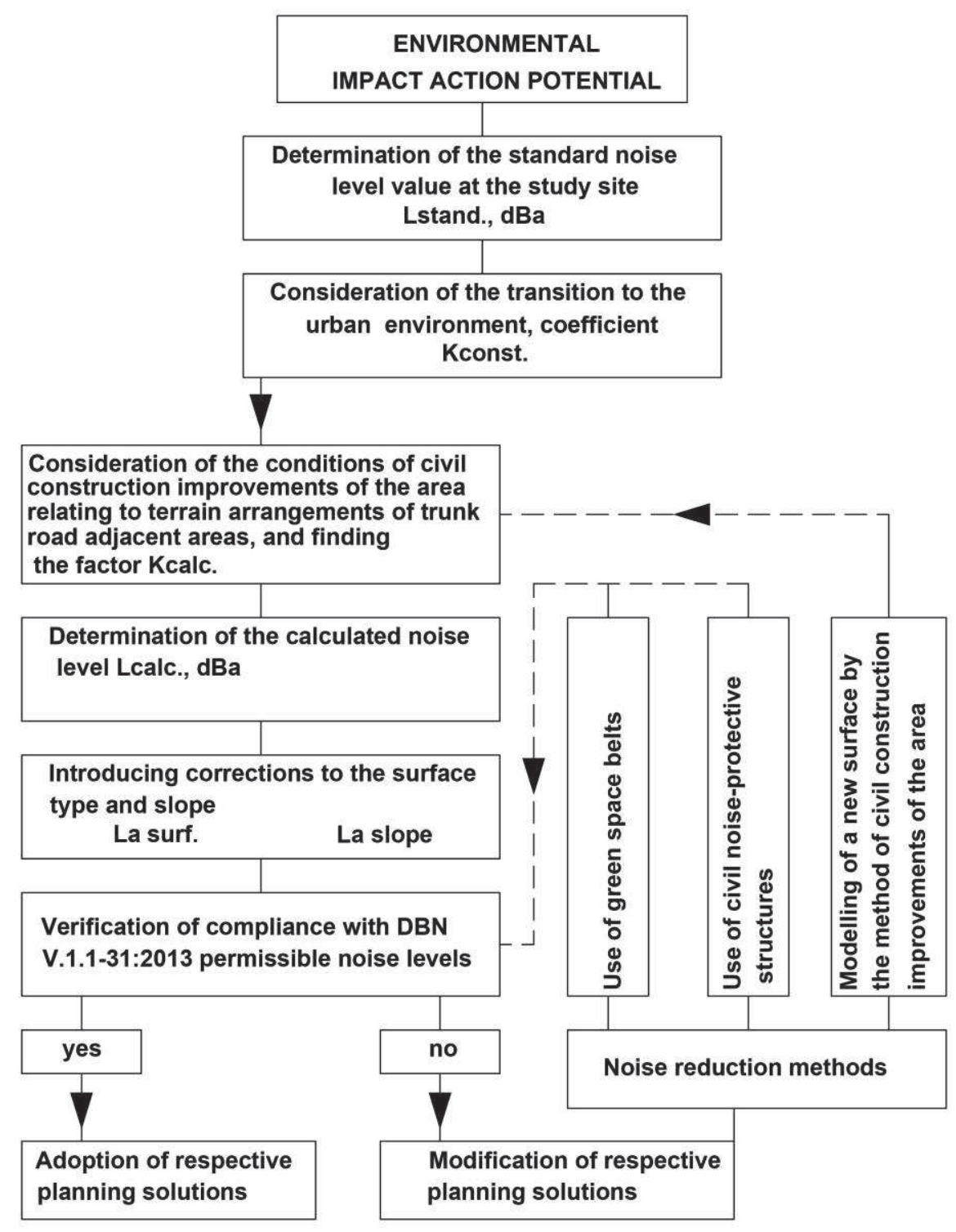

Fig. 4. Model of ensuring the effectiveness of regulation of the ecological-townplanning state of the main areas against noise exposure 
on urban areas, an approach is proposed to solve the problem at the level of functional area zoning, taking into account the degree of influence of ecological potential, depending on the characteristics of existing buildings and in terms of area renovation. This zoning approach can be taken as the basis for creating a safe, comfortable urban environment, sustainable and rational use with the appropriate functional purpose of the area, and sustainable urban development.

The study of Kyiv road network highways, construction line location, analysed area planning structure, area zoning diagrams and the terrain will determine the impact coefficient of noise distribution on the trunk road adjacent area.

The coefficients proposed can identify the influence of planning, engineering and technical solutions adopted or already implemented and to identify the relationship between urban planning features of residential build-up and routing of a given main street and road network, as well as its spatial development

The proposed principles of a multifactor approach applied to the developed example of the environmental impact of noise are presented in the form of a schematic structural model for ensuring the regulation of the ecological-town planning state of the main areas against noise exposure (Fig. 4) in the context of forecasting the potential impact on the state of urban development, which allows to determine the land surface transformation measures, arranging the terrain in the context of civil construction improvements of the area; this will enable the development of planning and urban development approaches to be continued

\section{CONCLUSIONS}

Relying on the expertise in theoretical and practical advances in the field of urban development and area planning, models have been developed in this study to ensure the effectiveness of regulation of the ecological-townplanning state of noise-affected trunk road adjacent areas; and they form the basis of the methodological support of environmental management of trunk road adjacent areas.

The motor transport influence on the ecological state of the urban setting under the conditions of ongoing motorisation growth has been described. Urban planning methods to reduce environmental impacts on trunk road adjacent areas are exemplified and developed using the elaborated models of environmental impact distribution that result from noise nuisance.

Noise nuisance field data in trunk road adjacent areas have been outlined. Based on the results obtained, a model was proposed for the conditions of regional and local area planning to determine noise pollution indicators.

The efficiency model has been developed for ecological-town-planning regulation of the functioning and development of trunk road adjacent areas in order to establish the environmental impact limit and forecasting with respect to the planning solutions adopted, to determine the area functionality and to choose civil construction improvements to protect the area.

Models of trunk network profiles were proposed with the definition of the spread of noise pollution in the adjacent trunk road areas, with the elements of the terrain's civil construction improvements in mind.

\section{REFERENCES}

1. State Construction Norm 360-92. City and City Planning. Planning and Development of Urban and Rural Settlements. Kyiv, Derzhbud Ukrainy, 113 (in Ukrainian).

2. General Planning Scheme of Kyiv for the period through to 2020, 2001. Main Principles, 69 (in Ukrainian).

3. Solukha B.V., Fuks H.B., 2003. Urban Ecology. Kyiv, KNUCA, 337 (in Ukrainian).

4. Furmanenko O.S., 1991, City and Country Cleaning and Refuse Disposal. Kyiv, Budivelnyk, 144 (in Ukrainian).

5. Astern M.M., Solukha B.V., Shilova T.O., 2010. Environmental Evaluation of City Main Road Crossings on Different Levels. Kyiv, KNUCA, 108 (in Ukrainian).

6. Ustynova I.I., 2016. Methodological Framework of Sustainable Development of Envi- 
ronmental City Planning Systems. Synopsis of a thesis, Kyiv, KNUCA, 46 (in Ukrainian).

7. Solukha I.B., 2016. Methods of Urban Environmental Evaluation of Traffic Planning Hubs in Trunk Road Networks of Large Cities. Synopsis of a Thesis, Kyiv, KNUCA, 22 (in Ukrainian).

8. Igor Solukha, 2015. The influence of longitudinal slope of main road carriage-way on the mass emission from road transport in the atmospheric air, MOTROL, Vol.17, No.08, 4551.

9. Annual Abstract of Statistics of Kyiv city, 2011. State Statistics Service of Ukraine, 467 (in Ukrainian).

10. Annual Abstract of Statistics of Kyiv city, 2015. State Statistics Service of Ukraine, 434 (in Ukrainian).

11. Osytnianko A.P., 2005. Kyiv Development Planning. KNUCA, 385 (in Ukrainian).

12. Priymachenko O.V., 2014. Determining the Planning Measures for Noise Reduction in the Areas Surrounding Main Roads. City and Land-Use Planning: Collection of scientific and technical articles. Kyiv, KNUCA, Iss.51, 469-474 (in Ukrainian).

13. Priymachenko O.V., 2014. Analysis of Models of Noise Propagation in Space. City and Land-Use Planning: Collection of scientific and technical articles. Kyiv, KNUCA, Iss.53, 435-439 (in Ukrainian).

14. Igor Solukha, 2015. Intersectional junctions of the main roads in city SRN System (on the basis of Kyiv SRN system). MOTROL, Vol.17, No.08, 53-59.

15. Ivanov V.N., Storchevus V.K., 1990. Ecology and Automobilization. Kyiv, Budivelnyk, 129 (in Russian).

16. State Construction Norm B.2.3-5-2001, Streets and Roads of Urban and Rural Settlements. Kyiv, 50 (in Ukrainian).

17. State Sanitary Rule 173-96, 1996. State Sanitary Rules of Planning and Development of Settlements. Kyiv, Ministry of Healthcare of Ukraine, 84 (in Ukrainian).

18. Guidelines on Development of the Chapter of Environmental Protection, Project to Construction Norms and Regulations, 1.02.01-85, 1989. Moscow, TSNII Proekt Gosstroya SSSR, 187 (in Russian).

19. State Construction Norm A.2.2.1-2003, 2003. Composition and Content of the Materials of Evaluation of Environmental Pressures (EEP) in Designing and Building Enterprises, Houses and Constructions. Main Principles of De- sign. Kyiv, Derzhbud Ukrainy, 19 (in Ukrainian).

20. State Construction Norm B.1.1-31:2013, 2013. Protection of Territories, Houses and Constructions from Noise. Kyiv, Minrehion Ukrainy, 75 (in Ukrainian).

21. State Standard of Ukraine DSTU-H B B.1.133:2013, 2013. Directive on Engineering and Design of Noise Protection of Residential Areas. Kyiv, Minrehion Ukrainy, 42 (in Ukrainian).

22. Ustynova I., 2015. Theoretical principles of wave urbanistics. Underwater Technologies, Vol.01, 33-42.

23. Shilova T.O., 2005. Analysis of acoustic conditions in Kyiv. City and Land-Use Planning: Collection of scientific and technical articles. Kyiv, KNUCA, Iss.20, 392-396 (in Ukrainian).

24. Bystriakov I.K., Shilova T.A., 1991. Estimation of paths of transport noise propagation when designing territorial integrated nature preservation systems. Abstracts of the reports of the All-Union Scientific and Technical Conference "Improvement of City Acoustical Environment: Development and Construction Methods". Sevastopol, 22-24 (in Russian).

25. Priymachenko O.V., 2017. Model for effectiveness evaluation of planning measures for protection of areas surrounding main roads from the influence of environmental pressures on the Kyiv main road network. Underwater Technologies, Vol.05, 67-73.

26. Osypova H.L., 1993. Noise protection in city planning. Designer Handbook. Stroyizdat, 96 (in Russian).

27. Samoiliuk E.P., Denysenko V.I., Pylypenko A.P., 1981. Noise control in population aggregates. Kyiv, Budivelnyk, 144 (in Ukrainian).

28. Priymachenko O.V., Shilova T.A., 2017. Determination of limits for acoustical pollution from main roads at the stage of urban area zoning. Underwater Technologies, Vol.07, 49-56.

29. Priymachenko O.V., Kobzar O., 2018. Methodology of studies for selecting engineering decisions in territory planning International scientific journal,Vol.1(1), 17-25. 


\section{Методология управления экологическим состоянием примагистральных территорий}

\section{Алексей Приймаченко}

Аннотация. В статье рассмотрены основные проблемы, связанные с исследованием и разработкой методологических основ экологоградостро-ительного регулирования процессов функционирования и развития магистральной улично-дорожной сети под влиянием экологических нагрузок от транспортных потоков и внешних факторов.

Необходимость разработки информационного обеспечения, научных исследований, научно обоснованных комплексных решений и методов выбора вариантов планирования и управления магистральных территориями является главной задачей исследования по созданию моделей управления экологическим состоянием и определения эффективности эколого-градостроительного регулирования процессами функционирования и развития примагистральных территорий, разработки моделей поперечных профилей магистральной улично-дорожной сети с возможностью установки размеров примагистральных территорий для обеспечения уменьшения влияния экологических нагрузки в жилой застройке и методов их эффективной защиты.

Ключевые слова: экологическое состояние городской среды, магистральные территории, экологические нагрузки. 